\title{
Enzymatic Treatment of Chronic Pancreatitis
}

\begin{abstract}
ALEXANDRU GRIGOROVICI ${ }^{1}$, DAN ANDRONIC ${ }^{2 *}$, DELIA HINGANU2*, MARIUS VALERIU HINGANU2*, FLORE VARCUS ${ }^{3}$
${ }^{1}$ Grigore T. Popa, University of Medicine and Pharmacy, Faculty of Medicine, I-st Surgical Department, 16 University Str., 700115, lasi, Romania

Grigore T. Popa, University of Medicine and Pharmacy, Faculty of Medicine, I-st Morpho-Functional Sciences Department, 16 University Str., 700115, Iasi, Romania

3Victor Babes, University of Medicine and Pharmacy, Faculty of Medicine, II-nd Surgical Clinic, 2 Eftimie Murgu Sq., 300041, Timisoara, Romania

The treatment of chronic pancreatitis consists of conservative and surgical treatment. The current development of interventional endoscopy techniques links the two above-mentioned treatments, offering less invasive solutions. In the treatment of chronic pancreatitis, a progressive approach is needed. Establishing any type of treatment is useless if the patient does not follow the recommendation to mainatin a proper diet. The study was conducted on a group of 61 patientshospitalized and operated for chronic forms of pancreatitis. Pancreatic insufficiency due to chronic pancreatitis is not a simple enzymatic deficiency, but an interactive complex of secretory, motor and endocrine functional disorders. Therefore, developing drug therapy will require not only the simple administration of enzymes in the intestine but also the restoration of the integrity of disruptive digestive functions.
\end{abstract}

Keywords:pancreatitis, enzymatic treatment, surgery

Generally, the treatment of chronic pancreatitis consists of conservative and surgical treatment. The current development of interventional endoscopy techniques links the two above-mentioned treatments, offering less invasive solutions.

In the treatment of chronic pancreatitis, a progressive approach is needed. Establishing any type of treatment is useless if the patient does not follow the recommendation to completely abstain from alcohol and/or drugs.

The pancreas synthesizes and secretes more than ten enzymes that hydrolyze carbohydrates, fats and proteins, especially in the lumen of the small intestine. In the evolution of chronic pancreatitis, secretory capacity of the pancreas and, implicitly, intraluminal digestion decrease. In chronic pancreatitis of alcoholic etiology, malabsorption usually does not occur earlier than ten years from the beginning of clinical symptomatology [1, 2]. As a result of the normal back up of pancreas secretory capacity, the inflammatory process must destroy more than $90-95 \%$ of the secretory parenchyma before malabsorption occurs.

To reduce malabsorption in exocrine pancreatic insufficiency, it is necessary to have a sufficient enzymatic level in the duodenal lumen at the same time with food penetration. Malabsorption occurs if this level is below $5-10 \%$ of the maximum normal enzyme flow rate. As a consequence, sialorrhoea can be prevented if during the digestion period the average level of lipase present in the duodenum chyme reaches $40-60 \mathrm{U} / \mathrm{mL}$. This means a required lipase intake of 35,000 - 40,000 $\mathrm{U}$ at each meal.

How ever, administering adequate amounts of lipase that reach undegradated in the duodenum encounters a number of difficulties. The ingestion of unprotected enzyme drugs is followed by the almost complete destruction of lipases by the gastric acid medium while the proteases pass through the stomach significantly better.
In addition to acid stomach denaturation, lipases from enzyme drugs are inactivated by proteolytic destruction in the intestinal lumen of patients with chronic pancreatitis, as well as an endogen lipase in healthy individuals. Only small amounts of active lipase are reaching into the duodenum and this requires administering an amount of five to ten times greater than that is intraduodenally necessary.

Pancreatic stimulation of digestion are hormonecontrolled and mediated processes[3].

Pancreatic insufficiency requires the initiation of substitution enzyme therapy as an etiological therapy for cystic fibrosis, pancreatic cancer, acute and chronic pancreatitis.

The first step in determining the effectiveness of using of pancreatic enzyme therapy is to determine whether malabsorption syndrome is due in most part to pancreatic exocrine insufficiency $[4,5]$.

The large number of tablets that the patient has to swallow makes it difficult to treat in the long time. On the other hand, capsules protected against gastric digestion are not superior to those unprotected because they remain in the stomach throughout the digestion period and are eliminated in the duodenum only late when digestion is complete. The efficacy of pancreatic enzyme preparations can be enhanced by gastric acid inhibitors: $\mathrm{H} 2$ blockers and Na-K pump blockers $[6,7]$. Another possibility is given by the appearance of entericprotected pancreatin microspheres.

\section{Experimental part}

Materials and methods

In 2010-2018, 612 patients with pancreatic disease were admitted to the Fourth Clinic of Surgery, lasi. Of these, 290 patients (47.39\%) had tumorous conditions (benign or malignant) and 322 patients (52.61\%) of inflammatory conditions.

Of the total patients diagnosed with pancreatitis, 61 patients were hospitalized and operated for chronic

\footnotetext{
*email :dan.andronic@umfiasi.ro; delia_f24@yahoo.com; hanganu.marius@yahoo.com
} 
forms ( $23.7 \%$ of total pancreatitis) and these represent the study group.51 patients were male and the avarage age was 41.6 years. The predominant symptom is pain, present in $90.1 \%$ of cases, followed by weight loss $(85.2 \%)$, steatore $(21.3 \%)$, obstructive jaundice $(16.4 \%)$ and digestive haemorrhage (5\%).

From the studied group, $81.9 \%$ of patients were operated in the first five years from the onset of the disease, $14.7 \%$ between 5 and 10 years, and 3.2\% after 10 years of evolution. The average development period was three years and nine months.

\section{Results and discussions}

Suppression of pain can be achieved by several conservative measures, for the vast majority of patients. Surgery is only necessary in cases where the pain is associated with the existence of an inflammatory tumor in the head of the pancreas or with amajor complication of the disease. The measures necessary for the conservative treatment of pain are diet, analgesics, therapeutic inhibition of pancreatic secretion and endoscopic maneuvers. Furthermore, some authors attempted to block celiac plexus or epidural anesthesia as the last conservative option before indicating surgical treatment.

Regarding the treatment of chronic pancreatitis, following the professional experience and research results of this group of patients, we propose a protocol for their management (table 1).

The results obtained from this study show that in most cases the substitution treatment of pancreatic function in patients diagnosed with chronic pancreatitis is efficient. Combating steathoreea and implicitly reducing the pancreatic enzyme requirement in the intestine significantly reduces painful symptoms, but also inflammatory and autophagic phenomena in the gland.In this regard, we propose a scheme for the application of drug treatment, customizable and adaptable according to the patients' response to the different types of pancreatic substitution medication (table 2).

In our study, we considered stabilized a patient without pain or with sporadic pain of low intensity, whose generall condition is good, which has increased in weight with an unchanged carbohydrate balance, over a period of at least five years.
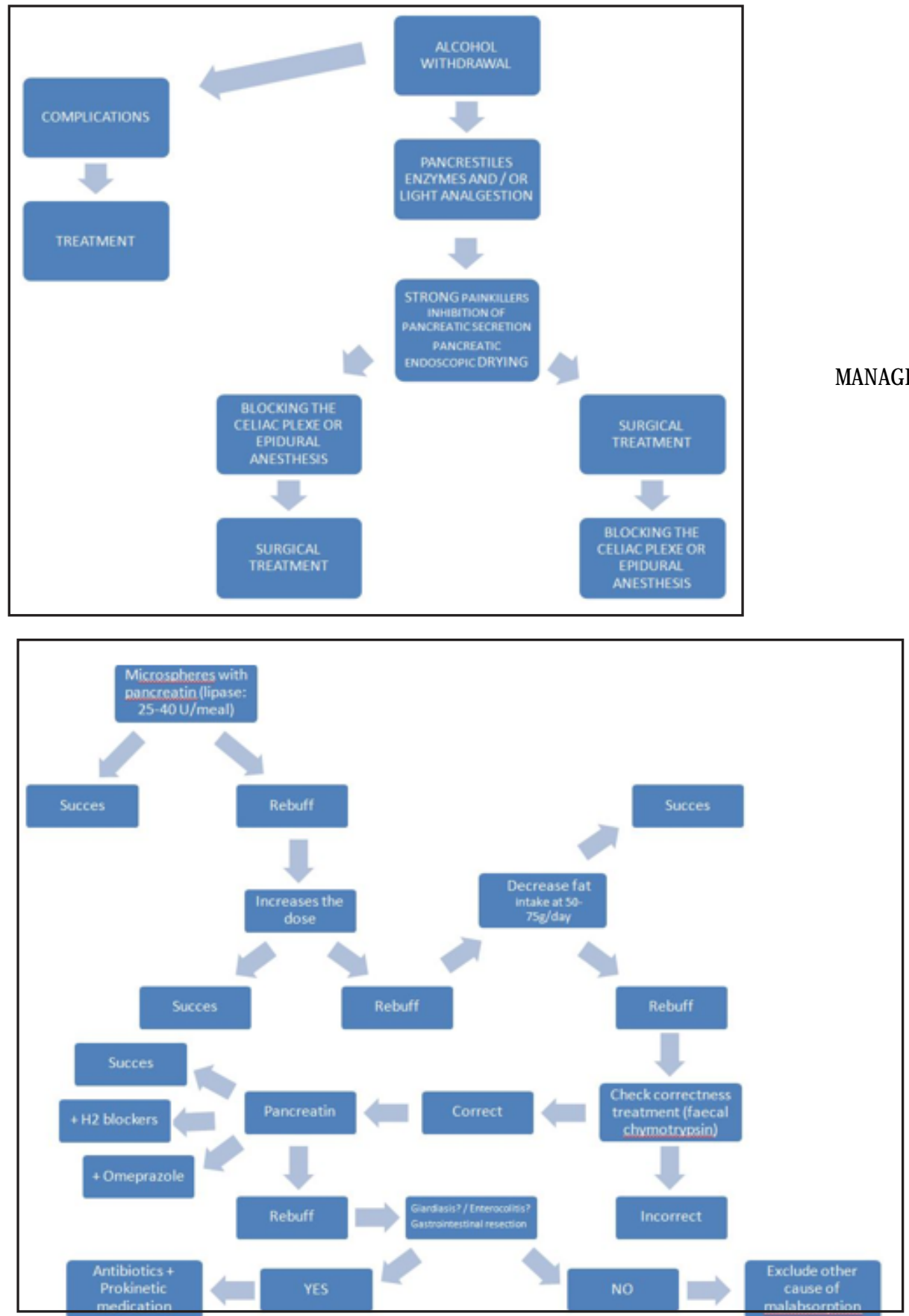

Table 1

MANAGEMENT PROTOCOL OF PATIENTS WITH CHRONIC PANCREATITIS
Table 2

ADAPTABLE SCHEME OF MEDICAL TREATMENT IN CHRONIC PANCREATITIS 
We considered as a failure a patient with further pains of the same intensity or higher compared to the period before the intervention and with a marked deterioration of the general condition. This result is mainly due to non-compliance with diet and alcohol abstinence.

For most patients with exocrine pancreatic insufficiency, enteric-protected microspheres (eg Creon) administered at the beginning of the meals are elective treatment.

On the contrary, patients with gastric resections or gastroenteroanastomoses who have an accelerated gastric emptying require administration of pancreatin granules or powder preparations. Patients with aclorhidhy, including those treated with IL-blockers or Na-K pump inhibitors, may be treated with conventional gastric unprotected pancreatin preparations.

It is very important to administer a sufficient dose of lipase; those of amylase and protease are less necessary in most patients. To decreasse a major steatorrhea to an acceptable level, a dose of at least 25,000 - 40,000 U lipase / lunch (at 4-5 meals / day) is required. In most cases, these doses need to be doubled. The effectiveness of treatment should be controlled primarily from the clinical point of view (body weight, stool consistency).

If the treatment response is unsatisfactory even at high doses of enzymes, patients need to change their diets in the sense of fragmenting them (5-6 small lunches / day) and reducing the amount of daily fat ingested to $50-70 \mathrm{~g}$. If and with these measures the patient's clinical condition does not improve, patient's compliance with the therapeutic indications should be checked. This can be done indirectly by dosing of the fecal chymotrypsin, which should be at a normal level in a patient who respects prescribed doses. If its value is low, an insufficient intake of additional enzymes should be suspected.

In these patients, the combination of proton blockers or omeprazole may be attempted, particularly in children with cystic fibrosis. Replacing fat from food with medium chain triglycerides can improve lipid absorption, but many patients complain about their unpleasant taste. Sometimes, especially in patients with gastrointestinal resections and intestinal infections with Giardia Lambi or bacteria, they can contribute to the malabsorption syndrome.

At present, the question arises whether existing enzyme preparations have a role not only in suppressing malabsorption but also in suppressing pain [8-10] in patients suffering from chronic pancreatitis. Existing data suggest that in severe pancreatitis most patients do not respond to medical treatment. It is assumed that in the near future a whole range of stable drugswith lipase will appear in the treatment of pancreatitis. However, their practical benefit will require a reserved appreciation.

Anti-inflammatory enzymes favor pancreatic dissolution and excretion, decrease the degree of pancreatic fibrosis and accelerate drug diffusion to the lesion [11-14]. Currently, new formulations of antiinflammatory enzymes are successfully prepared to improve their functional characteristics, pharmacokinetic properties and anti-inflammatory efficacy. They aim at increasing enzymatic stability and provide different routes of administration that improve their effectiveness and reduce their side effects and toxicity.

Medical treatment should ideally mimic the physiological intestinal status that is characterized by major digestion in the proximal intestine and the rapid decrease in lipolytic activity as intestinal chyme advances into the digestive tract [15-20]. Because enzyme replacement therapy is usually life-long, it is necessary to carefully study the potential side effects of these high-dose enzymes.

\section{Conclusions}

Pancreatic insufficiency due to chronic pancreatitis is not a simple enzymatic deficiency, but an interactive complex of secretory, motor and endocrine functional disorders. Therefore, developing drug therapy will require not only the simple administration of enzymes in the intestine but also the restoration of the integrity of disruptive digestive functions.

\section{Referrences}

1.DIMAGNO, E.P., GO, V.L.W., SUMMERSKILL, W.H. New England J ournal Of Medicine, 288, no.16, 1973, p. 813-815.

2.GATU, A., VELICESCU, C., GRIGOROVICI, A., DANILA, R., MUNTEAN, V., MOGOS, SJ., MOGOS, V., VULPOI, C., PREDA, C., BRANISTEANU, D. Acta Endocrinologica-Bucharest. 13, no.4, 2017, p.441.

3.BERRY, A.J . NUTRITION IN CLINICAL PRACTICE, 29, no.3, 2014, p. 312-321

4.DOMINGUEZ-MUNOZJE. Advances In Medical Sciences, 56, no.1, 2011, p. 1-5

5.HINGANU, D., HINGANU, M.V., MIHALCEANU, E., CALIN, A.M., PANGAL, A., COSTACHESCU, G., ROMILA, A., Rev.Chim. (Bucharest), 69, no. 3, 2018, p. 714.

6.DOMINGUEZ-MUNOZ J E, IGLESIAS-GARCIA J . J ournal Of The Pancreas, 11, no.2, 2010, p. 158-162

7.DUGGAN, S., O'SULLIVAN, M., FEEHAN, S. et al. NUTRITION IN CLINICAL PRACTICE, 25, no.4, 2010, p. 362-370

8.SCUTARIU, M.M., HINGANU, D., MACOVEI, G., HINGANU, M.V. Romanian Journal Of Oral Rehabilitation, 10, no.4, 2018, p.186.

9.ANDERSON, M.A., AKSHINTALA, V., ALBERS, K.M. et al. PANCREATOLOGY, 16, no.1, 2016, p.83-94

10. TOMA, A.G., SALAHORU P., HINGANU, M.V., HINGANU, D., DIMA COZMA, L. L., PATRASCU, A., GRIGORESCU C. Rev.Chim. (Bucharest), 70, no.1, 2019, p. 143.

11.YANG L, YAN SL, ZHANG YH, HU XY, GUO Q, YUAN YM, ZHANG JQ., International J ournal Of Pharmaceutics, 537, no.1,2018, p. 268-277

12.HINGANU, M.V., HINGANU, D., COZMA, S.R., ASIMIONOAIEISIMIONESCU, C., SCUTARIU, I.A., IONESIE, D.S., HABA, D. ANNALS OF ANATOMY, 220, 2018, p. 1.

13.DANILA, R., TESLOIANU, D.N., TIMOFTE, D., GHIZDOVAT, V., CIOBANU, D. ACTA CARDIOLOGICA, 72, no.6, 2017, p. 684-685

14.PREDA, C., VASILIU, I., BREDETEAN, O., GABRIELA, C.D., UNGUREANU, M.C., LEUSTEAN, E.L., GRIGOROVICI, A., OPRISA, C., VULPOI, C. ENVIRONMENTAL ENGINEERING AND MANAGEMENT JOURNAL, 15, no.4, 2016, p. 913-921

15. HINGANU, M.V., SALAHORU, P., HINGANU, D. Rev Med Chir Soc Med Nat lasi,122, no.3, 2018, p. 522.

16.COBZEANU, B.M., IRIMICIUC, S., VAIDEANU, D., GRIGOROVICI, A., POPA, O. Mat.Plast., 54, no.3, 2017, p.531.

17.GRIGOROVICI, A., CHERCIU, M.S., POPESCU, C.M., APOSTOL, D.G.C. , PREDA, C., CALIN, A., AELENEI, P. FARMACIA, 65, no.1, 2017, p.29.

18.GUPTA, V, TOSKES, PP. Diagnosis and management of chronic pancreatitis. POSTGRADUATE MEDICAL JOURNAL 2005: 81/958: 491-497.

19.VELICESCU, C., BRANISTEANU, D., GRIGOROVICI, A., GATU, A., PREDA, C., MOGOS, V., DANILA, R. ACTA ENDOCRINOLOGICABUCHAREST, 11, no.4, 2015, p.457-462.

20.GRIGOROVICI, A., COSTACHE, M., VELICESCU, C., SAVIN, G., CIOBANU, D., PREDA, C. CHIRURGIA, 105, no.5, 2010, p. 669-672. 